\title{
Efficiency of motivational tools and social media use in the control of canine obesity
}

\author{
Eficiência de ferramentas de motivação e do uso de mídia social no \\ controle da obesidade canina
}

\author{
Bruna Rodrigues Stafoche ${ }^{1}$ (D); Márcia Marques Jericó ${ }^{2}$ \\ ${ }^{1}$ Universidade de São Paulo, Faculdade de Medicina Veterinária e Zootecnia, Hospital Veterinário, Departamento de Clínica Médica, \\ São Paulo - SP, Brazil \\ ${ }^{2}$ Universidade Anhembi Morumbi, Hospital Veterinário, Departamento de Clínica Médica, São Paulo - SP, Brazil
}

\begin{abstract}
The increasing number of obese dogs in veterinary practice has been a warning to veterinarians about the need to develop new tools to approach the obese patient, aiming to attain satisfactory results in weight loss programs. A total of 18 obese or overweight dogs with no evidence of endocrine disorders were selected for this study. These animals were randomly divided into two groups with 9 animals each. In one of the groups, strategic tools were used by their tutors, aimed at behavioral and environmental modification, and this group was assisted daily through communication using a digital instant messaging app (WhatsApp ${ }^{\circledR}$ ). In the other group, these tools were not used, and the animals were followed only during the monthly consultation. The analyzed variable was the percentage of weight loss of each animal in one month of the method used. The animals of the daily assisted group had a mean weight loss of 5.17\%, while the animals of the non-assisted group had a mean weight loss of $3.31 \%$. Considering the results, one can state that the animals in the assisted group lost approximately 1.6 times more weight than the unassisted animals, when comparing the mean and the median weight loss percentage in the two groups. Although the results are encouraging, there was no statistical difference with a significance level of 0.05 , and this is probably due to the small sample size, consisting of 18 animals.
\end{abstract}

Keywords: Assistance. Strategies. Weight loss.

\section{RESUMO}

A crescente casuística de cães obesos na clínica de cães tem sido um alerta aos médicos veterinários sobre a necessidade do desenvolvimento de novas ferramentas para a abordagem do paciente obeso, com o intuito de alcançar resultados satisfatórios em programas de redução de peso. Nesse estudo, foram selecionados 18 cães obesos ou acima do peso ideal, sem indícios de distúrbios endócrinos. Esses animais foram divididos aleatoriamente em dois grupos de nove animais. Em um dos grupos foram utilizadas ferramentas estratégicas para modificação comportamental e ambiental para seus tutores e esse grupo foi assistido diariamente por comunicação em aplicativo digital de mensagens instantâneas (WhatsApp ${ }^{\circledR}$ ). No outro grupo, essas ferramentas não foram utilizadas e os animais foram acompanhados somente na consulta mensal. A variável analisada foi o percentual de perda de peso de cada animal em um mês de aplicação do método. Os animais do grupo assistido diariamente apresentaram média de perda de peso de 5,17\%, enquanto que os animais do grupo não assistido apresentaram média de 3,31\%. Pelos resultados é possível afirmar que os animais do grupo assistido perderam aproximadamente 1,6 vezes a mais de peso que os animais não assistidos. Embora os resultados sejam motivadores, não houve diferença estatística com grau de significância de 0,05 , isso provavelmente se deve ao número amostral de dezoito animais ser muito pequeno.

Palavras-chave: Assistência. Estratégias. Emagrecimento. 


\section{Correspondence to:}

Bruna Rodrigues Stafoche

Universidade de São Paulo, Faculdade de Medicina Veterinária

e Zootecnia, Hospital Veterinário, Departamento de Clínica

Médica

Av. Prof. Dr. Orlando Marques de Paiva, 87, Cidade

Universitária "Armando Salles de Oliveira"

CEP: 05508-270, São Paulo - SP, Brazil

e-mail: brunastafocher@msn.com

Received: September 12, 2018

Approved: July 05, 2019

How to cite: Stafoche BR, Jericó MM. Efficiency of motivational tools and social media use in the control of canine obesity. Braz J Vet Res Anim Sci. 2019;56(3):e150269. https://doi.org/10.11606/issn.1678-4456.bjvras.2019.150269

\section{Introduction}

Obesity is defined as the excessive accumulation of body fat, resulting from a chronic imbalance between the ingested amount of energy and the spent energy. Factors such as lifestyle (diet and physical activity), neuroendocrine changes and hereditary factors are associated with this imbalance (Marques-Lopes et al., 2004).

The excess of adipose tissue leads to deleterious effects on the physiological metabolism and organ function. Obesity is associated as the cause and with the progression of neoplasms, cardiorespiratory and urogenital system diseases, endocrine, dermatological and orthopedic diseases and metabolic disorders (Jerico \& Lorenzini, 2015; Kil \& Swanson, 2010; Lusby \& Kirk, 2009; Radin et al., 2009; Zoran, 2010).

According to Bland et al. (2010), in a survey where 419 Australian veterinary doctors answered a questionnaire on canine obesity, according to the opinion of the interviewed veterinarians, the main cause of obesity in dogs was identified as being related to the tutors.

Keeping the tutor involved and motivated during the weight loss process is crucial to treatment success. For veterinarians treating or preventing obesity in canine and feline patients, it is proposed that this behavioral modification construct be applicable when a behavioral change is intended by the pet's tutor. These are the motivational tools, where the tutors will be considered part of the weight loss plan, as they represent one of the main causes of animal obesity, given their role in the making and providing the pet's diet, their socioeconomic level and the level of activity in the pet's home. The tutors act as the patient when these motivational tools are applied, as they are responsible for carrying out the changes. These tactics may resonate especially with tutors of obese dogs (Murphy, 2016).

For example, according to German (2016), the rates of weight loss in dogs and cats vary at important stages during a complete weight loss cycle. In the first 28 days of a weight loss protocol, the mean rate of weight loss was $1.2 \%$ of body weight per week. Subsequently, weight loss decreases rapidly, so that after 12 months, the mean rate is $<0.3 \%$ per week. This slowing rate of weight loss occurs despite energy consumption being gradually reduced during the weight program, by 10 to $20 \%$. Such a reduction in the program effectiveness may contribute to the non-adherence to weight reduction programs by the tutor.

Therefore, convincing the tutors that their pets need to lose weight represents one of the main factors in program commitment and adherence. Motivational tools, such as the Five A's, are useful for approach and behavioral counseling. It was originally developed for human beings and adapted for dogs by Murphy (2016) using the words: Assess, Advise, Agree, Assist and Arrange.

Additionally, the SMART goal management tool can also be used. SMART is an acronym specifically developed for setting goals and objectives aiming to increase the performance and achievement of such goals. The SMART acronym was first written down in November 1981 in Spokane, Washington. George T. Doran, a consultant and former Director of Corporate Planning for Washington Water Power Company, published a paper entitled: "There's a S.M.A.R.T. Way to Write Management's Goals and Objectives." The most well-known goal-setting technique is SMART, which means, specific goals, measurable, assignable, realistic and time-related. (Haughey, 2014).

The management of animals during the assessment of the body condition score and the need to implement changes for weight management can be guided by the proposed use of the 5 A's adapted from Murphy (2016).

The aim of this study was to evaluate the influence of the daily follow-up of the dog's weight loss process through the use of motivational tools, consisting of filling in the files with the description of the activities and feeding the animal by the tutor, and by establishing communication in a group of dogs' tutors in the WhatsApp ${ }^{\circledR}$ social media app.

\section{Materials and Methods}

Over a period of one month, 18 dogs were selected at the Anhembi Morumbi University Veterinary Hospital. The animals presented Body Condition Score (BCS) between $7 / 9$ and 9/9, were of both male and female gender, of different breeds and aged between 2 and 13 years. Through 
anamnesis and physical examination, animals with evidence of endocrine diseases and those using glucocorticoids or barbiturates were excluded. The dogs were randomly assigned to two groups, the Assisted Group (AG) and the Unassisted Group (UG), with 9 animals each. Behavior change tools were employed only in the AG. The study was approved by the Research Ethics Committee for animal use of Anhembi Morumbi University (CEUA N. 0077201462).

The dietary anamnesis of all animals was performed according to the Purina Obesity Manual 2014 (Jericó et al., 2014), which collects information on all types of food the animal has access to, its amount and feeding frequency.

The BCS was evaluated with a nine-point scale system described by Laflamme (1997), which classifies the patient into categories, from cachectic $(\mathrm{BCS}=1)$ to severely obese $(\mathrm{BCS}=9)$, with $\mathrm{BCS}=4$ and 5 considered the ideal.

All selected animals received commercial dog food of the veterinary line for weight reduction manufactured by Purina Pro Plan Veterinary Diets OM - Overweight Management, with metabolizable energy of $299 \mathrm{kcal} / 100 \mathrm{~g}$. The amount of food was calculated according to the daily caloric requirement of each animal, for a certain target weight, according to the calculation described by Burkholder \& Toll (2000), as follows in Equations 1 and 2:

$R E R($ kcal / day $)=70 \times[$ target weight $(\mathrm{kg})] 0.75$

$D E R($ kcal / day $)($ dogs $)$ with a correction factor for weight loss $=1 \times$ RER where: RER is resting energy requirement; and DER is daily energy requirement.

In both groups, the recommendation for daily physical exercise varied from 20 to $30 \mathrm{~min}, 3$ to 4 times a week, as indicated by Lusby \& Kirk (2009). The proposed physical exercises were walking, hydrotherapy and "fetch the ball" for the previously described duration of time and in an uninterrupted manner.

The motivational tools, with daily follow-up, were used by the AG. The SMART goal management (Doran, 1981) was used, which established goals classified as specific (S), measurable (M), attributable (A), realistic (R) and for a determined period of time (T). This tool was filled out in ink, together with the animal's tutor in a printed sheet.

Also, the tutors were asked to fill out in ink a printed accompanying card daily, which contained data such as date, initial weight, goal weight and weight at the end (of each week), daily feeding, type of exercise performed, mistakes and successes that may have occurred during the day. Example of mistake: when the tutor does not resist and provides inadequate food for the animal, or when the animal "steals" some type of food. A success example is a long walk, longer than the planned one, or some enlightening activity of which the tutor should be proud, as it positively contributed to the animal's weight loss. Figure 1 illustrates the file model completed by the tutors daily.

\begin{tabular}{|c|c|c|c|c|c|}
\hline \multicolumn{6}{|c|}{ WEEKLY PLANNING FOR WEIGHT LOSS - SMART } \\
\hline \multicolumn{6}{|c|}{$\begin{array}{l}\text { DOG SNAME:- } \\
\text { OWNER: }\end{array}$} \\
\hline \multicolumn{6}{|c|}{ OWNER: } \\
\hline \multicolumn{6}{|c|}{ RESP ONSIBLE FOR FILING THIS PLAN: } \\
\hline \multicolumn{6}{|c|}{ WEEK - FROM: ___—_TO _ _ _ _ } \\
\hline \multicolumn{6}{|c|}{ INITAL WEIGHT:_____ } \\
\hline \multicolumn{6}{|l|}{ TARGET WEIGHT: } \\
\hline \multicolumn{6}{|l|}{ FINAL WEIGHT: } \\
\hline WEEK DAY & DATE & FEEDING & PHYSICAL EXERCISE & MISTAKES & HITS \\
\hline MONDAY & $2 / 20 / 18$ & $\begin{array}{c}\text { Proplan OM } \\
7 \mathrm{am} \mathrm{100 \textrm {g }} \\
2 \mathrm{pm} \mathrm{100 \textrm {g }} \\
9 \mathrm{pm} 100 \mathrm{~g}\end{array}$ & 30 minutes waikng & $\begin{array}{l}\text { Too tired } \\
\text { during } \\
\text { exercises }\end{array}$ & - \\
\hline TUESDAY & $2 / 21 / 18$ & $\begin{array}{l}\text { Pro Plan 0M } \\
8 \mathrm{am} \mathrm{100g} \\
3 \mathrm{pm} \mathrm{100g} \\
9 \mathrm{pm} 100 \mathrm{~g}\end{array}$ & 20 minutes walking & $\begin{array}{c}\text { Mel ate sice } \\
\text { of bread that } \\
\text { fell on the } \\
\text { floor. }\end{array}$ & - \\
\hline WEDNESDAY & $2 / 22 / 18$ & $\begin{array}{c}\text { Pro Plan 0M } \\
7 \mathrm{am} \mathrm{100g} \\
2 \mathrm{pm} 100 \mathrm{~g} \\
9 \mathrm{pm} 100 \mathrm{~g}\end{array}$ & - & No exercise & - \\
\hline THURSDAY & $2 / 23 / 18$ & $\begin{array}{c}\text { Proplan OM } \\
7 \mathrm{am} 100 \mathrm{~g} \\
2 \mathrm{pm} 100 \mathrm{~g} \\
9 \mathrm{pm} 100 \mathrm{~g}\end{array}$ & $\begin{array}{c}25 \text { minutes waking } 5 \\
\text { minutes running }\end{array}$ & - & $\begin{array}{l}\text { Willing to } \\
\text { exercise, } \\
\text { running }\end{array}$ \\
\hline FRIDAY & $2 / 24 / 18$ & $\begin{array}{l}\text { Proplan 0M } \\
7 \mathrm{am} \mathrm{100 \textrm {g }} \\
1 \mathrm{pm} 100 \mathrm{~g} \\
9 \mathrm{pm} 100 \mathrm{~g}\end{array}$ & - & - & \\
\hline SATURDAY & $2 / 25 / 18$ & $\begin{array}{l}\text { Proplan OM } \\
7 \mathrm{am} 100 \mathrm{~g} \\
2 \mathrm{pm} 100 \mathrm{~g} \\
9 \mathrm{pm} 100 \mathrm{~g}\end{array}$ & 20 minutes walking & - & - \\
\hline SUNDAY & $2 / 26 / 18$ & $\begin{array}{l}\text { Proplan OM } \\
7 \mathrm{am} 100 \mathrm{~g} \\
2 \mathrm{pm} 100 \mathrm{~g} \\
9 \mathrm{pm} 100 \mathrm{~g}\end{array}$ & 40 minutes walkng & - & $\begin{array}{l}\text { Extra exercise } \\
\text { day of week }\end{array}$ \\
\hline
\end{tabular}

Figure 1 - Weekly Planning for Weight Loss according to the SMART Tool for daily record by the owner. On the left side the blank plan, and on the right, an example of a filled-out plan. 
To reaffirm all recommendations for behavioral change, a mental exercise manual was created, as described by Murphy (2016) with self-affirmation phrases and correction of habits (Figure 2). This manual was handed to all tutors and its daily reading was proposed, aiming at reaffirming the concepts. The manual is unique and equal for all tutors.

Finally, for the assisted group (AG), daily follow-up was carried out through a digital instant messaging app (WhatsApp ${ }^{\circledR}$ ). A challenge was proposed to the participants, which included daily tasks, goals and specific objectives to be met so that the members' participation was active. At the end of the challenge, those who best met the required tasks would be offered an additional package of commercial dog food, encouraging the continuity of the weight loss program. The challenge follow-up was carried out by sending the daily task table as shown in the example in Figure 3.

For data analysis, the statistical analysis was performed using Student's $t$ test in the two sample groups, assuming different variances and considering values of $\mathrm{p}<0.05$ as statistically significant.

\section{WEIGHT LOSS PROGRAM}

\section{Mental Exercise for Behavioral Change:}

\section{Self-affirmation:}

- I am able to provide my pet with a safe home.

- I love my pet and want to provide it the best quality of life.

- I am able to provide toys to encourage activity for my pet.

- I can take great care of my pet and provide it an environment to encourage weight loss.

\section{Correcting habits:}

- If my pet sits next to me during my meals, then I will remove it from the kitchen (dining place) while l eat.

- If my pet is acting hungry, but it is not time to be fed, then I will take it for a walk or engage it in a playful activity.

- If my pet gains access to food sitting on my kitchen counter, then I

will place the food in a closed cabinet the pet cannot open

Figure 2 - Manual of Mental Exercise for Behavioral and Environmental Change. Source: adapted from Murphy, 2016.

\begin{tabular}{|c|c|c|c|c|c|}
\hline \multicolumn{2}{|c|}{ CHALLENGE } & \multirow{2}{*}{\begin{tabular}{|c|} 
Animal 1 \\
$\sqrt{ }$
\end{tabular}} & \multirow{2}{*}{\begin{tabular}{|l} 
Animal 2 \\
$\Lambda$
\end{tabular}} & \multirow{2}{*}{\begin{tabular}{|c|} 
Animal 3 \\
$\checkmark$
\end{tabular}} & \multirow{2}{*}{$\frac{\text { Animal } 4}{d}$} \\
\hline \multirow{3}{*}{$\begin{array}{l}\text { Week Day } \\
\text { (MM/DD) }\end{array}$} & Feeding & & & & \\
\hline & Exercise & $\checkmark$ & $x$ & $\checkmark$ & $x$ \\
\hline & Testimony & $\checkmark$ & $\mathbb{1}$ & $\mathbb{1}$ & $\mathbb{1}$ \\
\hline \multirow{3}{*}{$\begin{array}{l}\text { Week Day } \\
\text { (MM/DD) }\end{array}$} & Feeding & $\checkmark$ & $\checkmark$ & $\checkmark$ & $\checkmark$ \\
\hline & Exercise & $\checkmark$ & $\checkmark$ & $\checkmark$ & $\checkmark$ \\
\hline & Testimony & $\checkmark$ & $\Lambda$ & $\triangle$ & $\Delta$ \\
\hline \multirow{3}{*}{$\begin{array}{l}\text { Week Day } \\
\text { (MMM/DD) }\end{array}$} & Feeding & $\checkmark$ & $\checkmark$ & $\checkmark$ & $\checkmark$ \\
\hline & Exercise & $\checkmark$ & $\checkmark$ & $\checkmark$ & $\checkmark$ \\
\hline & \begin{tabular}{|l|} 
Testimony \\
\end{tabular} & $\checkmark$ & 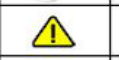 & $\Lambda$ & 1 \\
\hline \multirow{3}{*}{$\begin{array}{l}\text { Week Day } \\
\text { (MM/DD) }\end{array}$} & Feeding & $\sqrt{ }$ & $\sqrt{ }$ & $\sqrt{V}$ & $\checkmark$ \\
\hline & Exercise & $\checkmark$ & $\checkmark$ & $\checkmark$ & $\checkmark$ \\
\hline & Testimony & $\checkmark$ & $\Delta$ & 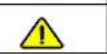 & $\Delta$ \\
\hline \multirow{3}{*}{$\begin{array}{l}\text { Week Day } \\
\text { (MM/DD) }\end{array}$} & Feeding & $\checkmark$ & 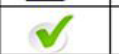 & $\checkmark$ & $\checkmark$ \\
\hline & Exercise & $\checkmark$ & $\checkmark$ & $\checkmark$ & $x$ \\
\hline & Testimony & $\checkmark$ & $\checkmark$ & $\checkmark$ & $x$ \\
\hline$\sqrt{ }$ & \multicolumn{5}{|c|}{ Task Completed } \\
\hline$\triangle$ & \multicolumn{5}{|c|}{ Pending Task } \\
\hline$x$ & \multicolumn{5}{|c|}{ Unfulfilled Task } \\
\hline
\end{tabular}

Figure 3 - Challenge Tracking in digital instant messaging application (WhatsApp ${ }^{\circledR}$ ). 


\section{Results and Discussion}

The animals were evaluated for one month (30 days). The measurable parameter that best reflected the response to the applied treatment was the weight loss percentage observed in the animals (Weight Loss \%). The tutors successfully interacted through the digital instant messaging app, WhatsApp ${ }^{\circledR}$. Every day, they sent information about their pets' routine, amount of food ingested, type and duration of the practiced exercises and videos that showed the physical exercise practice. The tutors clarified any doubts that appeared during the animal's treatment. The biggest challenge met while managing the instant messaging group was the constant attention and commitment by the group's coordinator to keep the participants involved and motivated.

The data on the AG and UG animals, as well as the weight loss evolution of each animal can be seen in Table 1 .

Although the data distribution was parametric, the mean and median values were determined to give a better picture of the data analysis. As the weight loss percentage results ranged from $1.83 \%$ to $9.76 \%$ in the AG and from $0.00 \%$ to $7.62 \%$ in the UG. We observed that the means and medians showed the same pattern of variation.

The mean weight loss percentage in the AG was $5.17 \%$, while it was $3.31 \%$ in the UG. The median weight loss percentage in the AG was $5.36 \%$, while it was $3.41 \%$ in the UG. Graph 1 shows the means and medians of the weight loss percentage in the two animal groups. It can be observed that the mean and median weight loss in the AG are higher than that in the UG. Based on the results, it can be inferred that the animals in the assisted group lost 1.6 times more weight than the unassisted animals, considering both the mean and median values, although the statistical analysis did not show a significant difference.

The statistical analysis showed a $\mathrm{p}$ value $=0.0964$ ( $p>0.05$ ), so there was no significant difference between the groups. The analysis can be seen in Table 2 .

The accessed literature did not show any similar studies, with emphasis on the canine species, where it was possible to compare the obtained results. The study was important to highlight the need for new approaches for the follow-up of patients undergoing weight loss treatment. In this study, it was possible to verify that the treatment established with goal setting, properly calculated diet, physical exercises, filling out the daily activities in forms and daily monitoring by the veterinarian through WhatsApp ${ }^{\circledR}$ promoting stimulatory activities had a positive contribution to the weight loss of the animals in comparison with the animals treated in a conventional manner, with a calculated diet, suggested exercises and monthly appointments.

Table 1 - Data and Evolution of Animals of the Assisted Group (AG) and Unassisted Group (UG).

\begin{tabular}{|c|c|c|c|c|c|c|c|c|c|c|}
\hline \multicolumn{11}{|c|}{ Assisted Group (AG) } \\
\hline Animal & Gender & $\begin{array}{c}\text { Age } \\
\text { (years) }\end{array}$ & Breed & $\begin{array}{l}\text { Reproductive } \\
\text { status }\end{array}$ & $\begin{array}{c}\text { Initial } \\
\text { BCS }\end{array}$ & $\begin{array}{c}\text { Initial } \\
\text { Weight (kg) }\end{array}$ & Final BCS & $\begin{array}{c}\text { Final } \\
\text { Weight } \\
\text { (kg) }\end{array}$ & $\begin{array}{l}\text { Weight } \\
\text { Loss (kg) } \\
30 \text { days }\end{array}$ & $\begin{array}{c}\text { Weight } \\
\text { Loss (\%) } \\
30 \text { days }\end{array}$ \\
\hline A1 & Female & 13 & Dalmatian & Spayed & 8 & 37.00 & 7 & 34.82 & 2.18 & $5.90 \%$ \\
\hline $\mathrm{A} 2$ & Female & 6 & Samoyed & Spayed & 8 & 37.40 & 7 & 34.68 & 2.72 & $7.27 \%$ \\
\hline A3 & Male & 3 & Golden retriever & Unneutered & 7 & 44.20 & 6 & 42.23 & 1.97 & $4.45 \%$ \\
\hline A4 & Male & 12 & Poodle & Neutered & 8 & 10.30 & 8 & 10.04 & 0.26 & $2.50 \%$ \\
\hline A5 & Female & 11 & Pinscher & Spayed & 8 & 5.60 & 7 & 5.28 & 0.32 & $5.71 \%$ \\
\hline A6 & Female & 2 & English Bulldog & Spayed & 8 & 31.50 & 8 & 30.32 & 1.18 & $3.75 \%$ \\
\hline A7 & Female & 8 & Mixed-breed & Spayed & 8 & 18.20 & 8 & 17.87 & 0.33 & $1.83 \%$ \\
\hline A8 & Female & 3 & Mixed-breed & Spayed & 8 & 19.70 & 6 & 17.78 & 1.92 & $9.76 \%$ \\
\hline A9 & Male & 13 & Labrador retriever & Neutered & 8 & 46.40 & 7 & 43.91 & 2.49 & $5.36 \%$ \\
\hline \multicolumn{11}{|c|}{ Unassisted Group (UG) } \\
\hline Animal & Gender & $\begin{array}{c}\text { Age } \\
\text { (years) }\end{array}$ & Breed & $\begin{array}{l}\text { Reproductive } \\
\text { status }\end{array}$ & $\begin{array}{l}\text { Initial } \\
\text { BCS }\end{array}$ & $\begin{array}{c}\text { Initial } \\
\text { Weight (kg) }\end{array}$ & Final BCS & $\begin{array}{c}\text { Final } \\
\text { Weight } \\
\text { (kg) }\end{array}$ & $\begin{array}{l}\text { Weight } \\
\text { Loss (kg) } \\
30 \text { days }\end{array}$ & $\begin{array}{c}\text { Weight } \\
\text { Loss (\%) } \\
30 \text { days }\end{array}$ \\
\hline B1 & Male & 2 & Border Collie & Neutered & 8 & 33.80 & 8 & 33.07 & 0.73 & $2.15 \%$ \\
\hline B2 & Female & 4 & Mixed-breed & Spayed & 8 & 8.20 & 8 & 7.94 & 0.26 & $3.14 \%$ \\
\hline B3 & Female & 4 & Lhasa Apso & Spayed & 8 & 9.50 & 8 & 9.14 & 0.36 & $3.76 \%$ \\
\hline B4 & Female & 11 & Pinscher & Spayed & 8 & 3.30 & 8 & 3.30 & 0.00 & $0.00 \%$ \\
\hline B5 & Female & 3 & Maltese & Spayed & 8 & 4.50 & 7 & 4.32 & 0.18 & $4.04 \%$ \\
\hline B6 & Male & 7 & Dachshund & Neutered & 8 & 18.00 & 7 & 17.36 & 0.64 & $3.54 \%$ \\
\hline B7 & Male & 2 & Golden retriever & Neutered & 8 & 59.40 & 8 & 58.15 & 1.25 & $2.10 \%$ \\
\hline B8 & Male & 5 & Golden retriever & Neutered & 8 & 50.80 & 7 & 46.93 & 3.87 & $7.62 \%$ \\
\hline B9 & Female & 4 & $\begin{array}{l}\text { Shetland } \\
\text { Sheepdog }\end{array}$ & Spayed & 8 & 22.70 & 8 & 21.93 & 0.77 & $3.41 \%$ \\
\hline
\end{tabular}




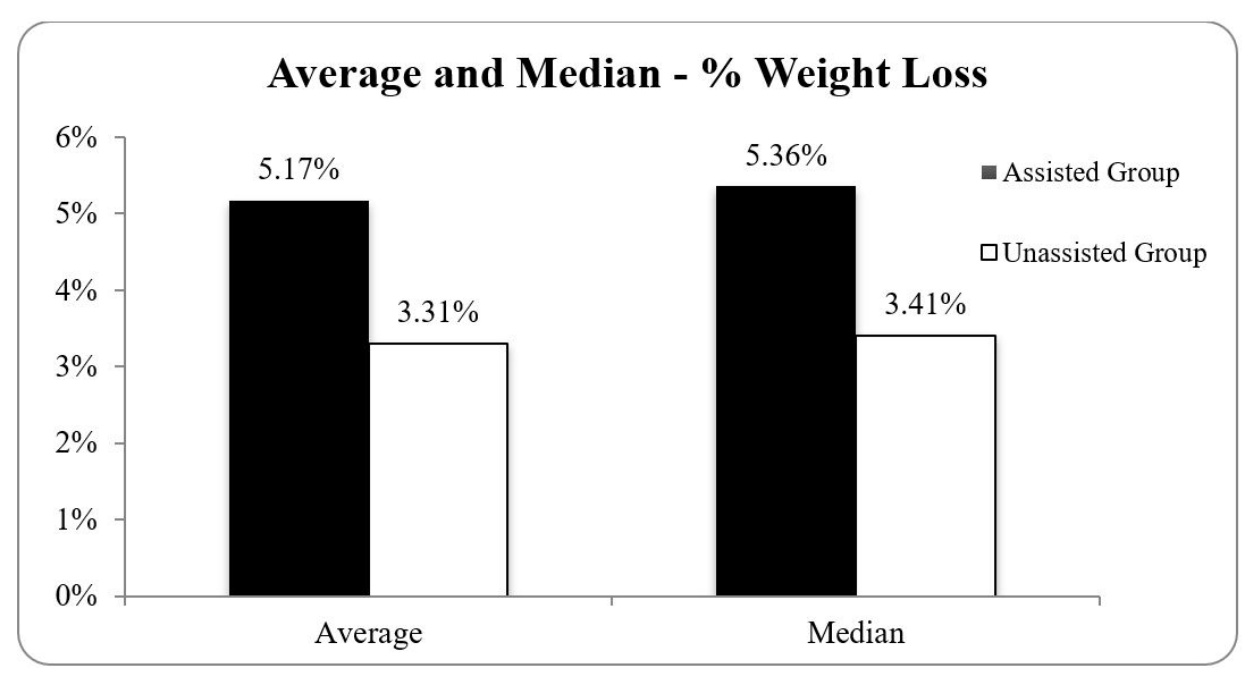

Graph 1 - Comparison between the average and median values of the weight loss in the Assisted Group $(\mathrm{n}=9)$ and in the Unassisted Group $(n=9)$.

Table 2 - Statistical Analysis by $t$-Test: two samples assuming different variances

\begin{tabular}{ccc}
\hline & AG & UG \\
\hline Mean & 0.051724057 & 0.033064084 \\
Variance & 0.00059009 & 0.000414426 \\
Observations & 9 & 9 \\
Hypothesized Mean Difference & 0 & 16 \\
$\mathrm{df}$ & 1.76625651 & \\
$\mathrm{t}$ Stat & 0.048211183 & \\
$\mathrm{P}(\mathrm{T}<=\mathrm{t})$ one-tail & 1.745883676 \\
$\mathrm{t}$ Critical one-tail & 0.096422366 & \\
$\mathrm{P}(\mathrm{T}<=\mathrm{t})$ two-tail & 2.119905299 & \\
$\mathrm{t}$ Critical two-tail & &
\end{tabular}

The duration of the study was set at 30 days, according to the period of greatest weight loss proposed by German (2016), which states that the highest average weight loss rates occur within the first 28 days of a weight loss protocol, reaching, according to his study, $1.2 \%$ of body weight per week in dogs and that, subsequently, weight loss decreases rapidly, even after diet adjustment.

The AG was the group with the majority of elderly animals (5 dogs older than 8 years), whereas, in the UG, only one animal was older than 8 years. This distribution may have contributed to a lower rate of weight loss in the AG, considering that the elderly animals' metabolism is slower, thus culminating in lower weight loss when compared to the younger animals. However, the tutors of the AG showed to be more involved in the obesity treatment of their dogs, as the contact and exchange of information between tutors helped reinforce the program's purpose every day, i.e., the need for dogs to lose weight so they can live a healthier life. Stimulation through rewards showed to be crucial as motivation and adherence factors for the tutors in the WhatsApp ${ }^{\circledR}$ group. During the periods where no reward was given for active participation in the group, the interaction was markedly lower than that observed when an additional commercial food package was provided to those who showed greater participation in the activities proposed during that week, a form of competitive activity among the tutors.

As the veterinary-tutor contact and relationship in the UG group was markedly lower, represented only by the monthly clinical consultation, and the fact that the tutors were not obliged to complete the daily follow-up form, and commitment to the project was not reinforced on a daily basis, the UG is presumed to be less adherent to the treatment. Moreover, it is noteworthy that this group consisted basically of younger animals, which contributed positively to a higher rate of weight loss, since the basal metabolic rate of younger animals tends to be higher.

The percentage of weight loss does not necessarily mean greater loss of fat mass; animals that practice more exercise are more likely to lose fat mass and maintain muscle mass, 
which would result in lower total weight loss. It is believed that the AG animals practiced more physical exercises than the UG animals, according to the tutors' reports and the daily reminders aimed at the AG tutors in the WhatsApp ${ }^{\circledR}$ group.

Two animals were excluded at the start of the screening of program participants for suspected endocrinopathy. These two animals were not involved in the program, so they are not included among the 18 selected animals. The study had some limitations, such as the small number of treated animals, and the short period of time. Moreover, the tutors' interaction in the WhatsApp ${ }^{\circledR}$ application group has limited application; the implementation of these tools can be difficult in case of tutors who do not have mobile devices (which are currently rare), but it is a factor to be considered as an impediment for the implementation in specific populations. The contact by telephone is indicated in these cases.

\section{Conclusion}

Although the mean and median differences between the two groups were not significant, when the descriptive values were compared, the animals in the assisted group showed higher weight loss. Based on the results, it can be stated that the animals in the assisted group lost 1.6 times more weight than the unassisted animals. This lack of significance may be due to the small number of animals enrolled in the present study.

\section{References}

Bland IM, Guthrie-Jones A, Taylor RD, Hill J. Dog obesity: veterinary practices and owners' opinions on cause and management. Prev Vet Med. 2010;94(3-4):310-5. http:// dx.doi.org/10.1016/j.prevetmed.2010.01.013. PMid:20167383.

Burkholder WJ, Toll PW. Obesity. In: Hand MS, Tatcher CD, Remillard RL, Roudebusch P, editors. Small animal clinical nutrition. 4th ed. Topeka: Mark Morris Institute; 2000; p. 401-30.

Doran GT. There's a S.M.A.R.T. way to write management's goals and objectives. Manage Rev. 1981;70(11):35-6.

German AJ. Weight management in obese pets: the tailoring concept and how it can improve results. Acta Vet Scand. 2016;58(Suppl 1):57. http://dx.doi.org/10.1186/s13028016-0238-z. PMid:27766974.

Haughey, D. A brief history of SMART goals [Internet]. Project SMART. 2014 [cited 2017 Nov]. Available from:
Furthermore, it was possible to verify that the tutors of the animals in the assisted group showed greater commitment to the weight loss process and were more committed due to the continuous stimuli of the behavioral and environmental alteration tools.

This work can be viewed as a pilot for future research involving a larger number of animals and for a longer period of time, so that it is possible to prove the effectiveness of the daily contact between the veterinarian and the tutors of obese dogs with the use of daily monitoring tools, as well as the interaction in a group of tutors using social media.

\section{Conflict of Interest}

The authors state that they have no conflicts of interest to declare.

\section{Ethics Statement}

The research meets all applicable standards regarding the ethics of experimentation and the integrity of research.

\section{Acknowledgements}

To Nestlé-Purina for providing the commercial food applied in this experiment. To Anhembi-Morumbi University and Veterinary Hospital for allowing this study.

https://www.projectsmart.co.uk/brief-history-of-smartgoals.php

Jericó MM, Lorenzini F, Kanayama K. Manual de obesidade canina e felina. São Paulo: Associação Brasileira de Endocrinologia Veterinária; 2014.

Jericó MM, Lorenzini F. Obesidade. In:Jericó MM, Kogika MM, Andrade JP No, editors. Tratado de medicina interna de cães e gatos. 1a ed. Rio de Janeiro: Roca;2015. Chapter 197; p. 3129-52.

Kil DY, Swanson KS. Endocrinology of obesity. Vet Clin North Am Small Anim Pract. 2010;40(2):20519. http://dx.doi.org/10.1016/j.cvsm.2009.10.004. PMid:20219484.

Laflamme DP. Development and validation of a body condition score system for dogs. Canine Pract. 1997;22(1):10-5. 
Lusby AL, Kirk CA. Obesity. In: Bonagura JD, Twedt DC, editors. Current veterinary therapy XIV. Missouri: Saunders Elsevier; 2009; p. 191-5

Marques-Lopes I, Marti A, Moreno-Aliaga MJ, Martínez A. Aspectos genéticos da obesidade. Rev Nutr. 2004;17(3):327-38. http://dx.doi.org/10.1590/ S1415-52732004000300006.

Murphy M. Obesity treatment: environment and behavior modification. Vet Clin North Am Small Anim Pract. 2016;46(5):883-98. http://dx.doi.org/10.1016/j. cvsm.2016.04.009. PMid:27264054.
Radin MJ, Sharkey LC, Holycross BJ. Adipokines: a review of biological and analytical principles and an update in dogs, cats, and horses. Vet Clin Pathol. 2009;38(2):13656. http://dx.doi.org/10.1111/j.1939-165X.2009.00133.x. PMid:19392760.

Zoran DL. Obesity in dogs and cats: a metabolic and endocrine disorder. Vet Clin North Am Small Anim Pract. 2010;40(2):221-39. http://dx.doi.org/10.1016/j. cvsm.2009.10.009. PMid:20219485.

Financial Support: None.

Authors Contributions: Bruna Rodrigues Stafoche and Márcia Marques Jericó participated in the writing of the article, considering the reading and review stages. 